\title{
Ermeni Kilisesinin Koruması Altındaki Ermeni Terörü
}

\author{
DOI: 10.26466/opus.787716
}

\author{
Elnur Pașa * \\ * Dr. Öğr. Üyesi, Osmaniye Korkut Ata Üniversitesi \\ E-Posta: elnurpasa@yahoo.com \\ ORCID: $\underline{0000-0001-6723-7617}$
}

\begin{abstract}
Öz
Bu çalışmada bir terör faili ve destekçisi olarak Ermeni Kilisesinin tutumu, ayrıca Rusya ve Batı'nın bu durum karşısındaki tavrı ve yaklaşımı ele alınmıştır. Ermeni terörizminin ideolojik temelinin oluşmasına, örgütlenmesine ve maddi imkânlara erişimine ilk katkının hiç şüphesiz Kilise tarafından yapıldı̆̆ın görebiliriz. Ermeni Kilisesi, Ermeni geleneklerini korumadaki rolünün yan sıra Ermeni milliyetçiliğinin gelişmesinde ilk adımları atmıştır. Böylelikle Gregoryen Kilisesi bu politikanın ve ayrllıkçılı̆̆ın gelişmesini güçlü bir şekilde desteklediler. Yüzyılı aşkın bir dönemi kapsayan Ermeni Gregoryen Kilisesi'nin doğrudan mali desteği ve himayesi altında gerçekleşen terör eylemleri ve sonuçları tartışılmaktadır. Ermenilerin terörist eylemlerde bulunmalarının amacı diğer milletlere karşı şovenist, bölücü ve saldırgan politikaların gerçekleştirmek isteğinden kaynaklanmaktadır. Komşu ülkelerin bütünlüğ̈̈ne kastederek işgal politikasını uygulayan Ermenistan, bu niyetini açık şekilde ortaya koymaktadır. Makalede değinilen önemli hususlardan biri de Hristiyan Avrupa'nın Ermeni terörüne, Ermeni Kilisesinin faaliyetlerine karşı objektif olmayan tavrı ve hukuka uygun bir yaklaşımın yokluğudur. Tarihi karşılaştırma ve paralellikler kurarak Ermeni terörünün gerçek yüzünü ortaya koymak bu çalışmanın hedeflerinden biridir.
\end{abstract}

Anahtar Kelimeler: Ermeni terörü, Ermeni kilisesi, Ermeni şovenizmi, Batının desteği, Hristiyan dayanışması 


\title{
Armenian Terror Under The Protection Of The Armenian Church Summary
}

\begin{abstract}
The article reflects the issues of the Armenian Church as a religious subject of terrorism and its protection of Armenian terrorism. Undoubtedly, the church made the first contribution to the formation of the ideological foundations of Armenian terrorism, their organization and access to financial resources. The Armenian Church, along with its role in preserving Armenian traditions, has taken the first steps in the development of Armenian nationalism. Thus, the terrorist acts carried out under the direct financial support and patronage of the Gregorian Church, covering a period of more than a century, and their consequences are discussed. The purpose of committing terrorist acts is also the desire of Armenians to pursue policies of chauvinism, separatism and aggression against other nations. This reveals their intention to create and expand their own state at the expense of other people's lands. One of the important points mentioned in the article is the reasons for the non-objective attitude of Christian Europe to the Armenian terror, the lack of legal assessment of the activities of the Armenian Church. Historical comparisons, parallels, researches conducted on the basis of the approach of different researchers allow to determine the true nature, realities, goals and objectives of Armenian terrorism.
\end{abstract}

Keywords: Armenian terror, Armenian Church, Armenian chauvinism, Western support, Christian solidarity 


\section{Giriş}

Günümüzde terörü İslam'a ilişkilendirmeye çalışan Hristiyan dünyası aslında bunun gerçek olmadığının farkındadır. Tarihi gerçekler, Ermeni Gregoryen Kilisesi'nin daha 19. yüzyıldan itibaren terörün dini boyutunu temellendirmeye ilişkin çalışmalar yaptığını göstermektedir. Bu gerçek tek başına bile birçok şeyi ifade ediyor. Ermeni Kilisesi'nin uluslararası terör unsuru olarak suça iştirakı temsil ettiği Hristiyanlığın imajını zedelemektedir. Ermeni terör eylemlerinin özü sadece terör eylemleri değil, aynı zamanda başta Azerbaycanlılar ve Türkler olmak üzere çeşitli halklara karşı toprak iddiaları, onların toprakları sayesinde kendi devletlerini kurma istekleri ve dolayısıyla şovenizmin, ayrılıkçılık ve işgal politikasıdır. Diğer bir deyişle, uluslararası terörün bir parçası olan Ermeni terörü örgütlü ve iyi şekilde organize edilmiştir. Faaliyete başladığı ilk günden bu yana Ermeni terörünün amacı barışa, güvenliğe, Türkiye ve Azerbaycan Türklerine, genel olarak insanlığa saldırmaktır (Gunter, 1986, s.24). Yıllar boyunca planlanmış ve hedefe yönelik uygulanan bu şovenist politika artık tüm dünyanın açıkça gördüğü bir gerçektir.

Bu nedenle İslam'i terörle ilişkilendirmeye çalışan Avrupa ülkelerinin öncelik olarak Ermeni terörü ve destekleyicileri başta olmakla Hristiyanlığ zedeleyen faktörlere kaşı birlikte mücadele etmeleri daha doğru olacaktır. Sadece bu durumda uluslararası terörle mücadelede etkili sonuçlar elde edilebilir. Aksi takdirde uluslararası hukuka yönelik çifte standart sergilemek, sorunu herhangi bir din veya milliyetle ilişkilendirmek doğru bir yaklaşım değildir ve böyle bir yaklaşım çözüm yollarını tıkamaktadır. Ne yazık ki, uluslararası terörü siyasi emellerine alet etme, onu farklı amaçlarla kullanma eğilimleri değişik terör örgütleri gibi Ermeni terörünün de Azerbaycan topraklarında, aynı zamanda işgal ettikleri Dağlık Karabağ ve çevre ilçelerde, Türkiye, Avrupa ve diğer ülkelerde terör faaliyetlerine devam etmesine zemin hazırlamaktadır. Ermeni Kilisesi'nin teröre yardım ve yataklık eden ve doğrudan faili olarak karakterize eden hususlarının açıklanmasını belirtmeye gerek yoktur. Ermeni kiliselerinin kuruluşu, amaç ve hedefleri, özellikle onu terörün faili olarak karakterize eden özellikler açık şekilde kendini göstermektedir. Bu bağlamda, terörü İslam ile ilişkilendirmeye çalışan Batı'nın, Hristiyan toplumunun, Ermeni Kilisesi'nin terörü desteklemesi ve himaye etmesi çok da şaşırtıcı değildir. Siyasi ve tarihsel 
analizler, karşılaştırma ve paralellikler, bilimsel ve teorik açıklamalar, makalenin ana konusunu teşkil eden Ermeni terörünün mahiyet itibariyle daha fazla açıklanmasın olanak sağlamaktadır.

\section{Ermeni İhaneti, Gregoryenleștirme Politikası Ve Rusya'nın Himayesi}

Ermeni terörü, uluslararası terörizmin ayrılmaz bir parçası olduğu için nihai hedefi siyasidir. Şöyle ki, bu eylemler 19. yüzyılın sonlarında ivme kazanmaya başlayan ve Batılı ülkelerin desteğiyle uygulanmaya çalışlan "Büyük Ermenistan" kurma planlarının ideolojik temelini oluşturmaktadır (Qazıyev, 2009, s.58-60). Bu ideoloji, Ermenilerin her açıdan diğer milletlerden üstün olduğunu, Ermeni milletinin "yüce" ve "uluslar üstü" olduğu tezini, buna karşılık "tarihi mağduriyet" yaşadıkları ve bu "adaletsizliği" ortadan kaldırmanın önemli olduğunu iddia etmektedir (Qurbanov, 2005, s.91). Ermeniler, kurguladıkları "tarihi adaletsizliği" ve "haksızlığı" ortadan kaldırmak için terörü temel baskı ve tehdit aracı olarak görmektedirler.

Ermeni terörizminin ideolojik temellerinin oluşması, örgütlenmesi ve finansmanı kilise tarafından sağlanmaktadır. Ermeni geleneklerinin korunmasında özel bir role sahip olan Ermeni Kilisesi, Ermeni milliyetçiliğinin gelişmesinde öncül rol oynamıştır. Gregoryen Kilisesi ve Batılı misyonerler Ermeni milliyetçiliğinin yükselişine büyük katkı sağlamışlardır. Gregoryen Kilisesi, Ermeni devletinin yokluğunda sadece dini değil, aynı zamanda Ermeni toplumunun siyasi koruyucusu olarak işlev görmeye başlamıştır. (Hüseynov, 1999, s.4). Başka bir deyişle, devletin olmaması, Ermenilerin kilisenin etrafındaki yoğunlaşmasını tetiklemiştir. Kilise liderleri siyasi propaganda yapmakta, halkı çeşitli siyasi ve askeri güçleri desteklemeye çağırmış ve bu amaçla bağış toplamışlardır.

Bunun yanı sıra komşularına ihanet ederek Arap halifelerine sığınan ve yabanc işgalciler tarafından korunan Gregoryen Kilisesi, misyonerleri aracılığıyla komşu bölgelerde aynı zamanda Kafkasya Albanyası'nın bazı bölgelerinde yaşayan yerel Alban-Hristiyan halk arasında Gregoryenliği yaymaya başladılar. Sonra zorla Gregoryenleştirilen Alban-Azerbaycan kabilelerinin Ermenileştirilmesi süreci yaşanmıştır. Böylece Hilafet döneminde Gregoryen Kilisesi'nin dini etki alanı Güney Kafkasya'ya doğru genişlemeye başlamıştır. 
Gregoryen misyonerlerin Güney Kafkasya'ya gelişi, ilk başta dinsel çatışma, ardından etnik çatışmalar daha sonra ise kıyımlar dönemini başlatmıştır. Arap halifeliğinin zayıflamasından sonra, Gregoryen Kilisesi bu kez Azerbaycan Türk devletlerine -Karakoyunlular, Akkoyunlular, Safeviler ve son olarak Osmanlı İmparatorluğu'na sığınmıştır (Hüseynov, 1999, s.5).

Azerbaycan'ın Karakoyunlu devletinin diğer etnik gruplara ve dinlere karşı hoşgörülü ve korumacı tavrını kendi çıkarları için kullanan Gregoryen Kilisesi, merkezini Azerbaycan'ın tarihi toprakları (bugünkü Ermenistan)Eçmiadzin'e taşımıştır. Akkoyunlu ve Safevi hükümdarlarının Ermenilere ve Ermeni Katolikosuna olumlu yaklaşımına rağmen Ermeniler, tarihsel koşulların değişmesine bağlı olarak her üç Azerbaycan devletine ihanet etmişlerdir. Daha sonra Gregoryen Kilisesi ve Ermeniler Osmanlı padişahları tarafından koruma altına alınmıştır. Zamanla Ermeniler, Osmanlı İmparatorluğu'nun kendilerine tanıdığı eşit hakları suistimal ederek siyasi, askeri ve mali alanlarında önemli mevkileri ele geçirmişlerdi. Fakat Ermeni Kilisesi'nin sürekli yoğun faaliyetleri sonucunda güçlü bir milliyetçi ideolojiye sahip olan Ermeniler, toplu halde yaşadıkları Osmanlı İmparatorluğu topraklarında hükümete itaatsizlik ederek devlete karşı ayaklanmışlardır.

Bu konuyla ilgili olarak Amerikalı yazar J. McCarthy "Türkler ve Ermeniler: Ermeni Sorununa Yönelik Bir Kılavuz" adlı kitabında şöyle yazar: “Ermeni milliyetçileri 1870'li yillardan başlayarak Anadolu'daki yurttaşlarmı Türk hükümetine karşı ayaklanmaları için kışkırtmaya başladılar. Bu süreç ilk defa 18 Mart 1878'de Ingiltere'nin Türkiye'deki Büyükelçisi Layerd tarafindan dile getirilmiştir. İmparatorluğun Ermeni nüfusunun dini lideri ile yaptığı görüşmelerden birinde Ermeni azınlı̆̆n Türk hükümetini devirerek Türk topraklarryla birlikte Rusyayla birleşmeğe hazırlandıkları hakkında bilgi almıştır" (McCarthy, J. ve McCarthy, C., 1989, s.43-44). "Hınçak" partisinin terörist mahiyeti örgütün programını gösteren belgeye açık şekilde yansımıştır: Türkiye'deki deorim terör yapılarak gerçekleşmelidir. Insanlara ilham vermek için terör şarttır. Terör, halkı korumanın bir yöntemi, halkın güvenini kazanmanin bir yoludur. Parti, Osmanlı devletine karşı terörü desteklemektedir (Memmedov, 2002, s.346).

Tüm bunlar Türkiye'de yaşayan Ermeniler arasında ayrılıkçı-terörist eğilimlerin yaygın bir şekilde geliştiğini ve Ermeni Kilisesi tarafından desteklendiğinin açık şekilde göstermektedir. Gerek Türkiye topraklarında gerekse Azerbaycan topraklarında yerleşmiş Ermeniler daha sonra bu topraklara hak iddia ederek, bu toprakların kendilerine ait olduğunu dünyaya ispat- 
lamaya çalışmışlardır. Fakat Ermenilerin sadece Türklere ve Azerbaycanlılara değil hatta onları koruyup kollayan Ruslara karşı da ihanet ettikleri unutulmamalıdır. Buna rağmen onlar Ruslar olmadan yapamayacaklarının da farkındadırlar. Keza onların Güney Kafkasya'daki emellerinin gerçekleşmesi yolunda en büyük destekçileri Rusya'dır. Büyük hedeflere ulaşmak için her zaman Rusya'ya sığınan Ermeni şovenistler, zaman zaman kendilerine yardım eden ve kendilerine önemli ayrıcalıklar tanımış Osmanlı Devleti'ne ve Azerbaycan'a ihanet etmişlerdir. Kuşkusuz bu durum, Rusya'nın jeopolitik çıkarlarına da hizmet etmektedir.

Rusya'nın 18. yüzyılda Güney Kafkasya ve Anadolu'ya yönelik politikasında Ermenileri önemli bir araç olarak kullanması dikkate şayandır. I. Petro, Güney'e gönderdiği ajanlarına Rusya'nın bölgede güvenebileceği gücü belirleme talimatını vermiştir. Bu güç Ermeni toplumu olacaktır. Bu sayede ilerleyen tarihlerde Güney Kafkasya'da Çarlık Rusya'sını destekleyecek bir Hıristiyan devletin kurulmasına zemin hazırlanmıştır. Bu sinsi planı hayata geçirmek için öncelikle, Azerbaycan' daki Türkiye yanlısı Sünni nüfusu daha sonra İran yanlısı Şii nüfusu yok etmek gerekecekti (Memmedov, 2002).

Mesela, 1808'de Çar I.Aleksandr (1801-1825), Ruslara yardım etme amaçlı casusluk faaliyetleri nedeniyle Ermeni Kilisesi Katolikosu Daniel'i birinci derece Aziz Anna madalyasıyla ödüllendirmiştir. Bunun karşılığında Ermeni Kilisesi sürekli olarak Rusların batıya saldırarak Osmanlı topraklarının derinliklerine kadar ilerlemesine yardımcı olmuş ve düzenli olarak Rusları, kendilerini "Müslüman zulmünden" kurtarmaya çağırmıştır (Samuel, 2004: 34). Ermeni Kilisesi Hiristiyan Ermeniler ile Müslüman Osmanlılar arasındaki nefretin artmasına hizmet etmiştir. Ruslar da Osmanlı topraklarını işgal eder etmez Ermeni Kilisesi ile beraber Müslüman halkı tazminat ödemeden kovmuş, onların ev ve arazilerine Ermenileri yerleştirmiştir.

Daha sonra bu politikayı sürdüren II. Nikolay, Kafkasya ziyareti sırasındaki konuşmasının sonunda şunları söylemiştir: "Rus bayrağı İstanbul ve Çanakkale'de serbest bir şekilde dalgalansin. Ermeni halkı Rusya'nın yardımıyla Osmanl devleti topraklarında bağımsız devletlerini kursunlar." Bu, Ermenilere onları Rusya tarafına çekmek için bir mesajdı (Ermeniler terörizmin en iğrenç formasından istifade ederler, 2004). 


\section{Ermeni Kilisesi'nin Ermeni Terör Örgütlerine Desteği}

Ermenilerin separatist ve terör faaliyetlerinin daha geniş çaplı yayılması, 10 Şubat 1828'de Türkmençay Antlaşması ile Güney Azerbaycan'ın Marağa şehrinden Karabağ topraklarına göç ettirilmesinden sonra başlamıştır (bu olay 1978 yılında Ermenilerin Ağdara bölgesine göç ettirilmesinin 150. yıldönümü anısına diktikleri anıtla doğrulanmaktadır. Anıtın üzerinde Ermenice "Marağa-150" yazısı yazılmıştır (Brief informations of the history of Garabagh, 2005, s.9; Rau, 2008, s.22). Özellikle de I. Nikolay'ın fermanıyla 21 Mart 1828'de Azerbaycan topraklarında sözde idari birim olan "Ermeni vilayeti" nin kurulması bu politikanın gerçekleşmesinde olanaklar sağlamıştı (Hüseynov ve Memmedov, 2019: 16-21). Bunu takiben 1836'da Ermeni Gregoryen Kilisesi'nin kışkırtmasıyla bağımsız Alban Kilisesi tasfiye edilmişti. Bu tarihten itibaren Rusya'nın koruyup kolladığı Ermeniler Azerbaycan ve Anadolu'da Türk-Müslüman halka karşı geniş çaplı katliamlara başlamıştı. Ermeni Kilisesi, faaliyetlerini ve olanakların genişleterek, önde gelen Ermeni parti ve kuruluşlarıyla yakın ilişkiler kurup birçok alanda anlaşarak 19. ve 20. yüzyılın başlarında değişik ülkelerde birçok Ermeni okulu açmayı başarmışlardır. Özellikle 19. yüzyılın sonlarında Ermeni milliyetçileri, Gregoryen Kilisesi'nin "kutsaması" ile daha örgütlü faaliyete başlamışlardı.

"Taşnaktsutyun" partisi ile Ermeni-Gregoryen Kilisesi arasındaki ilişkileri gösteren Rus araştırmacı N. Shavrov şöyle yazar: "Bu zaman (yani Knez Golitsın'ın Kafkasya naibi olduğu dönemde) "Taşnaktsutyun" partisini başkanı Ermeni Kilisesi psikoposuydu ve devrimci hareketin önemli liderlerinin yanı sira devrimci çalışmalara harcamak amacıyla para toplayanlar da din adamlarmın ta kendileriydi (Şavrov, 1990). Özellikle de "Büyük Ermenistan" adlı akla ziyan bir planı gerçekleştirmeyi amaç edinen radikal-terörist Ermeni örgütleri, farklı ülkelerde faaliyetlerde bulunarak ilişkiler kurmaya ve bir ağ oluşturmaya başlamıştır. Bu örgütlerinden bazıları şunlardır: "Armenakan" Partisi (1885), "Hınçak" Partisi (1887), "Taşnaktsutyun" - Ermeni Federal Devrimci Partisi (1890), “Ermeni Soykırımı Adalet Komandoları" (1972), "Ermenistan'ın Bağımsızlığı Uğruna Gizli Ordusu (ASALA) ( 1975), “Ermeni Özgürlük Hareketi" (AOD) (1991), "Ermeni Özgürlük Cephesi" (1979), “Orli Grubu” (1981), “İntihar Filosu” (1981), “Dağllk Karabağ Devrimci Yönetim Komitesi - KRUNK" (1987), “Ermeni Birliği" (1988), “Genç Ermeniler Birliği” (1990), “9 Haziran Grubu” (1991), “İsviçre Grubu” (1991), “Özgürlük Kaplanları” 
(1991), “Gegaron" (2001). "Apostol" (2001) ve diğerleri. (Ehmedov, 2012: 1542). Bunlardan birçoğu ASALA'nın yan kuruluşları olarak kurulmuş ve çeşitli Avrupa ülkelerinde terör eylemleri gerçekleştirmişler. Belirtilen terör örgütlerinin terörist niteliğini ispatlamak için bazı argümanlara bakmak isabetli olacaktır. 1887' de kurulmuş Ermeni-milliyetçi partisi olan "Hınçak", resmi programında terörü amaç edinerek Osmanlı İmparatorluğu topraklarında bağımsız Ermeni devleti kurmayı kendilerinin ana hedefi olarak görmekteydi. Bu örgüt aynı zamanda "Türklere ölüm" çağrısıyla kanlı suçlar ve terör eylemleri gerçekleştirmeye başlamışlardır (Mahmudov, 2009, s.8390).

Bunun yanı sıra Ermeniler ilk terör eylemlerini onların "politikasını" desteklemediği için Kafkasya Sivil İşler Başkanı Knez Golitsın’a karşı gerçekleştirmişlerdi (14 Ekim 1903).

1890 'da kurulan bir diğer milliyetçi-terörist Ermeni partisi "Taşnaktsutyun" da Türkiye topraklarında bağımsız bir Ermeni devleti kurmayı hedeflemişti. Bu planının gerçekleştirilmesi için Osmanlı İmparatorluğu topraklarında "Büyük Ermenistan" propagandasının güçlendirilmesi, silahlı terörist grupların oluşturulması ve devlet dairelerinin yağmalanması gerekiyordu. "Taşnaktsutyun" partisi fiilen teröristlerin yer aldıkları silahlı gruplardan oluşmaktaydı. Bu husus, onu siyasi bir kuruluştan ziyade silahlı terör örgütü olduğunu kantlamaktadır. (İmanov, 2006, s.24-35). Dönemin tarihi kaynakları, kurulduğu günden beri Taşnakların Ermeniler arasında milliyetçiliği ve terörü kışkırttı̆̆ını, diğer milletlere karşı düşmanlık ve nefret uyandırmaya çalıştı̆̆ını, Kafkasya ve Osmanlı İmparatorluğu'na karşı Çarlık Rusya'sının müttefiki rolünü oynadığını doğrulamaktadır. Her iki örgüt mensupları Doğu Anadolu ve Azerbaycan köylerini yağmalamaktaydı. Hatta "Büyük Ermenistan" hastalığına yakalanan Ermeni teröristler çkarlarını karşılamayan gayrı Türk milletlere de zulmetmeye başlamışlardı (Memmedov-Asadov, 1992, s.44; Memmedov, X. ve Memmedov, N, 2006, s.14-15).

Ermeni terör örgütlerinden "Devrimci Ermeni Federasyonu" kurulduğu ilk günden beri mahiyetine uygun faaliyet göstermeye başlamış ve Birinci Dünya Savaşı'ndan sonra Ermenistan'ı kontrol altına almayı başarmıştı. Diğer örgütler gibi bu örgüt de Ermeni Kilisesi tarafından desteklenmekteydi. Bunu kanıtlaması açısından şu olaya bakmak yeterlidir: Aralık 1882'de Erzurum'da 76 Ermeni tutuklandı. Tutuklananlar "Vatanı müdafaa 
cemiyeti" üyeleriydi. Onlardan kırkı terör eylemlerinden dolayı beş ila on beş yıl hapis cezasına çarptırıldılar. Buna rağmen büyük kısmı Patrik Nerses ve Piskopos Ormanya'nın istirhamı üzerine bir yıl sonra Sultan tarafından affedildiler. 1886 'da cezaevindekiler de affedildi (Kennet, 2002, s.56-57). Ermeni Kilisesi'nin söz konusu terör örgütlerini desteklemedeki amacı bireysel terör eylemlerini değil, daha geniş biçimde kitlesel terörü yaygın hale getirerek daha fazla insan öldürme ve daha ciddi sonuçlar almaktı.

Kilisenin örgütlenmesini kanitlayan en önemli hususlardan biri, terörün daha düşünülmüş ve daha organize bir şekilde gerçekleştirilmesiydi. Hatta 19. yüzyılın sonlarında ve 20. yüzyılın başlarında organize bir biçimde, ırk ayrımcllı̆̆ına dayalı terör eylemleri Ermeni milli basını ve edebiyatı tarafından desteklenmeye, ağır cinayetler işlemiş teröristler halka kahraman olarak tanitılmaya başladı. Bu tutumun kesintisiz olarak devam etmesi tesadüf değildir. Hâlihazırda Rusya, Amerika Birleşik Devletleri, Fransa ve diğer ülkelerin televizyonlarında ve medya kanallarında çalışan pek çok Ermeni bu amaca hizmet etmektedir. Bu insanlar ellerindeki firsatları kullanarak yapmış oldukları vahşeti gizlemeye, örtmeye ve kendilerini dünyaya masum ve mazlum bir halk olarak tanıtmaya çalışmaktadırlar.

\section{Ermeni Kilisesi'nin Karakteristik Faaliyetleri}

Yukarıda bahsedildiği gibi, Ermeni terör örgütleri genellikle 19. yüzyılın ikinci yarısından başlayarak faaliyet göstermeye başlamıştır. Kilisenin doğrudan girişimleriyle birçok örgüt yeraltı faaliyetlerini sürdürerek hükümet dairelerine saldırmakta, hükümet yetkililerini katletmekte, bölgelerde terör eylemleri ve isyanlar çıkarmakla uğraşıyorlardı. Dünyanın farklı yerlerinde terör eylemlerine başvurmaları onların tüm insanlığa karşı düşmanca tutum takındıklarının bir göstergesidir. Şunu da belirtmemiz gerekir ki, Amerika Birleşik Devletleri'nde sadece 1980-1990'l1 yıllarda yaşanmış terör eylemlerinin tahminen \%25'i Ermeni terör örgütleri tarafından gerçekleştirilmiştir (Armyanoskoye genosid, 1992, s.40). Fakat Ermeni terör faaliyetlerinin büyük kısmı Türkiye ve Azerbaycan'da gerçekleşmiştir. Mesela, Gregoryen Kilisesi'nin terör örgütü olarak faaliyete 20. yüzyılın başlarında Bakü'de bariz şekilde ortaya çıkmıştır. Şöyle ki, 12 Haziran 1903'te, Kafkasya Sivil İşler Başkanı Knyez G. Golitsin'ın Ermeni Kilisesi'nin malvarlığı Rusya Top- 
rak ve Emlak Bakanlığına devredilmesini öngören başvurusu kanun olarak imzalanmıştır. Bu kararın ardından Ermeni Kilisesi dâhil tüm Ermeni örgütleri Çar yönetimine karşı suikast ve terör eylemleri düzenlemeye karar vermişlerdi. Bu kanun, Ermeni kiliseleri tarafından finanse edilen siyasi partilerin mali durumunu ciddi şekilde etkilediği için Ermeni terörizminin yayılmasına, Rus ve Müslüman karşıtı duyguların yükselmesine yol açtı.

Tiflis'te kurulan Ermeni Kendini Savunma Merkez Komitesi, 12 Haziran 1903 tarihli yasayı yürürlükten kaldırmak için Çarlık yönetimine karşı mümkün olan her tür yönteme başvurarak savaşacağını açıklamıştı (Azerbaycan Respublikasının Prezidentinin). Ermeniler 11 Mayıs 1905 tarihinde saat 3'te, Ermeni Kilisesi civarında Parapet Bahçesi (şimdiki Fevvareler Meydanı) ile Vorontsov (şimdiki Mirza İbrahimov) sokağının kesiştiği noktada, Bakü Genel Valisi Knyez Mihail Nakaşidze'nin faytonuna bombalı saldırıda bulunmuşlardı. Saldırıda Nakaşidze ve yardımcısı, ayrıca o sırada olay mahalindeki iki Azerbaycanlı hayatını kaybetmişti. Patlamanın sorumluluğunu "Taşnaktsutyun" Partisi Merkez Komitesi üstlenmiştir (Gumbatov, 2006).

1914'te Ermeni dini lideri Katolikos V. George'nin Türkiye'deki tüm Ermenilere seslenerek onları savaşta Ruslara yardım etmeğe çağırması Osmanlı İmparatorluğu'nda yaşayan Ermeni olmayan sivil ahalinin Ermeni terörüyle karşı karşıya kalmasıyla sonuçlanmıştı. "Büyük Ermenistan” düşüncesinden esinlenen Ermeni Kilisesi, Türkiye'de toplu terörizmle bağımsız bir Ermeni devletinin kurulabileceğini umuyordu.

19. yüzyılın başından 20. yüzyılın başına kadarki dönemde Ermeni dini kurumlarının Ermeni terörüne öncülük yaptığını doğrulayan faaliyetleri şu şekilde özetlenebilir:

- Ermeniler arasında radikal milliyetçilik-şovenizm ideolojisinin yayılmasi;

- İdeolojik ve psikolojik bakumdan donantml Ermeni teröristlerin hazırlanmasi;

- Türkiye'de yaşayan Ermeniler arasında milliyetçi, ayrnlıkçı ve terörist eğilimlerin artmasl;

- Kitlesel terör planlarmm hazırlanmasinda ve uygulanmasinda örgütlenme ve teşvik (Qurbanov, 2004, s.25).

Ermeni kiliselerinin terörizme destek vermesi yukarıda belirtilen tarihi dönemle sinırlı değildir. Günümüzde de Ermeni din kurumları terörizmin savunucusu olarak faaliyetlerine devam etmektedirler. Esat Uras'ın “Tarihte 
Ermeniler ve Ermeni Meselesi" adlı kitabında Ermeni terör örgütü ASALA'ın en yakın müttefiki ve destekçisinin Ermeni Kilisesini olduğunu, terör konusunun Ermeni din adamları arasında asla eskimediğinin bir göstergesidir (Esat, 1987).

Günümüzde Ermeni Kilisesi terör faili olarak Ermeni terör örgütlerinin finanse etmektedir. "Karabağ'da güçlenen ASALA terör örgütü yurt dışındaki Ermeni Katolik kiliselerinden maddi ve fiziki yardım almaktadır. Çeşitli şekilde yapılan yardımlar "Ermeni milli kimliğinin, tarihinin ve geleneklerinin korunması" adı altında gerçekleşmektedir. Türkiye, İran, Rusya, Ermenistan ve diğer ülkelerde çalışan Ermeni iş adamları, Ermeni kiliseleri aracilığıyla "Haydat" örgütünün banka hesaplarına istedikleri zaman gizli şekilde yardım gönderebilmektedirler" (Haydad, 2001, s.77-79).

Ermeni Kilisesi ideolojik ve psikolojik yönüyle hazırlıklı terörist yetiştirme çalışmaların günümüzde de sürdürmektedir. Hâlihazırda ASALA'nın birkaç radikal kanadı faaliyettedir. Onlar kilise tarafından birtakım görevleri gerçekleştirmek adına talimatlar alıyor. Bu operasyonlar Amerika Birleşik Devletleri, İngiltere, Almanya, Fransa, Suriye, Lübnan, Pakistan, İran ve Rusya'da bulunan gruplar tarafından gerçekleştiriyor. ASALA'daki radikal kanatlardan birinin adının kilise adı olması tesadüf değildir -"Tayva" (Haydad, 2001, s.79).

Ermeni Kilisesi bu planların sadece hazırlanmasında değil, aynı zamanda uygulanmasında rol almaktadır. ASALA'nın "Bölgelere!” isimli broşürlerinin dağıtımı sırasında Geşan, Keşişkend, Kuropatkin, Alekseyevka, Abdal, Malıbeyli, Zarıslı, Şuşa, Çanakçı ve diğer kiliselerdeki temsilciler Hankendi'ye gelmiş, Seyavuş Bagdasaryan bölge rahiplerine "Büyük ve Kutsal Ermenistan" hakkında bilgi vererek kilisenin bu planların gerçekleştirilmesindeki rolünü açıklamaktadır. "Bölgelere!" adlı broşürün bir bölümünde "Kilise annemizin beşiğidir..." yazar. Bu görüşten anlaşılacağı üzere Kilise, Ermeni halkının ideolojik temelinin ve stratejik düşüncesinin oluşumunda baskın bir role sahip olmanın yanı sıra terörist olarak yetişmelerinde de etkili olmuştur. Bu çalışmalar eskiden sıradan bir başpiskopos olan ve sonradan hizmetleri sayesinde Ermenilerin yeni Katolikosu olarak seçilen Garagen Nersesyan tarafindan yönetilmekteydi. O 1975'te Almanya'da rahip olduğu sırada ASALA'nın en güçlü ve "en bilge" destekçisi olarak tanınıyordu. Yüksek Ruhani Konsey üyesi olan bu din adaminın yolu Moskova'da Genel İstihbarat Teşkilatıyla kesişmişti. Nersesyan 1979'da Mosko- 
va'daki Rus Ortodoks Kilisesi'nin doktorasında eğitime başlamış, mezun olduktan sonra tekrar Erivan'a dönmüştü. O sırada Nersesyan'ın programında "eksik kalmış bir sayfa" vardı - Karabağ sayfası ... (Novruzoğlu, 2002, s.112-113).

Günümüzde Ermeni terör örgütlerinin kilise karşısında hesap vermeleri Ermeni Kilisesi'ni terör faili olarak nitelendiren önemli hususlardan biridir. Bu durum, Ermeni Kilisesi'nin küresel çaptaki Ermeni terörizminin ön saflarında yer aldığını doğrular niteliktedir. Farklı ülkelerde Ermeni diasporasının güdümündeki kiliselere gönderilen "Önünüzde eğiliyoruz" isimli rapor bu yöndeki siyasi çalışmaların doğrudan bir sonucudur. Bu raporda farklı Ermeni cemaati temsilcilerinin, Karabağ' daki silahlı birliklerde görev yapan yüksek rütbeli subayların, toplama kampındaki doktorların, ayrıca gözlemcilerin konuşmalarından alınmış parçalar, yazılarından alınmış görüş ve yorumları içermektedir (Qurbanov, 2004, s.27). Kiliseye gönderilen aylık ve yıllık raporlarda her Ermeni'nin kaç Azerbaycanlı öldürdüğünü coşkuyla belirtmesi dikkate şayandır. Mesela, raporların birinde şöyle bir not mevcuttur: “... birkaç yıl önce takımlara ayrıldık. Takımlar, kimin kaç Azerbaycanlıyı öldüreceği konusunda birbirleriyle yarışlar düzenledi. Öldürmek konusunda pek fazla düşünmüyorduk. Azerbaycanlıysa, demek ki ölmesi gerekir. O bizim düşmanımız$d \imath r^{\prime \prime}$ (Novruzoğlu, 2002, s.117-118).

\section{Batı Ülkelerinin Ermeni Terörizmi Karşısındaki Tutumu}

Yüz yılı aşkın süreyi kapsayan Ermeni terörünün hedefi sadece Türkler ve Azerbaycanlılar değil tüm insanlıktır. Yani Ermeni terör örgütleri tarafından Türkiye ve Azerbaycan'da gerçekleştirilmiş sayısız terör eylemlerinin yanı sıra 1973-2001 yılları arasında sadece Batı Avrupa ülkelerinde 235 terör eylemi işlenmiş, 41 kişinin öldürülmesine teşebbüs edilmiştir. Bu terör eylemleri sonucunda 524 kişi yaralanmış, 105 sivil rehin alınmıştır (Mustafayeva, 2002, s.145). Örneğin Amerikalı ünlü araştırmacı alim Samuel Weems "Ermenistan Terörist-Hristiyan Ülkenin Sırları" adlı kitabında sağlam kanıtlarla “1918 yılından günümüze kadar Ermenistan'ın iki önemli ihracı olduğunu yazar: kendi "tarihi vatan"larmdan yurtdışıa akm eden milleti ve terör! (Samuel, 2004, s.122). Yazar ayrıca Ermenilerin, devletlerini diğer halkların toprakları üzerinde inşa etmeye çalıştıklarını, her zaman Türklere karşı insanlık dışı kanlı eylemlerle akıllarda kaldıkların belirtmektedir. Ermenilerin hain ni- 
yetlerini ortaya koyan bilim adamı, Ermenilerin yaşadıkları devlete ve halka düşmanca tutumunu saklamadığını ve bunu terör eylemleriyle daha çok sergilediklerini bildirmektedir. İlginç hususlardan biri de yazarın kitapta Ermenilerin Hıristiyanlığına kuşkusuyla yaklaştı̆̆ını göstermesidir.

Zira terör eyleminde bulunan Ermeni Kilisesi ve diğer terörcü örgütlerini hedefinde sadece Anadolu ve Azerbaycan Türklerinin yaşadıkları yerler değil, aynı zamanda diğer halkların yaşadıkları bölgeler de yer almaktadır. Nitekim Ankara ve İstanbul'un yanı sıra Frankfurt, Lahey, Roma, Milano, Viyana, Amsterdam, Paris, Beyrut, Tahran, Bern, Ottawa, Lizbon, Rotterdam, Köln, Zürih, Brüksel, Madrid, Cenevre, Kopenhag, Marsilya, Atina, Lyon, Strazburg, Sidney, Lozan, gibi şehirler de Ermeni terörünün yayılma alanı kapsamındadir (Samuel, 2004, s.158- 159).

Ne yazık ki Ermeniler ve onların terör örgütleriyle ilgili görüşler genellikle Hıristiyan bilginlerin kitaplarında ve yazılarında bulunmakta ve doğrulanmaktadır. Siyasi çevreler ve yönetici elitler gerçekleri açıkça kabul etmekten kaçınırken, bir Hristiyan devletinin ve Hristiyan Kilisesi'nin mali yardımını ve organizasyonu sayesinde teröre verdiği desteği gizlemeye çalışıyorlar. Yukarıda belirtilen şehirlerde gerçekleştirilen terör eylemleri, Ermeni terörünün hedefinin Müslüman olmayan Hiristiyan halkları bile kapsadığının bir kanıtıdır.

Bu tutumu ve nitelikleri itibariyle Ermenistan, dünyanın en kapalı Hıristiyan toplumlarından biridir. Ermenistan'ın sadece bir "resmi" kilisesi vardır. Bu kilise devletin bir parçasıdır ve Ermeni anayasası kiliseye önemli ayrıcalık tanımıştır. Ermenistan adlanan küçük toprak parçasında kilise ile devletin ayrılması söz konusu değildir ve ikisinin birbiriyle bağlantılı olması terörizmi destekleme politikasının bir gereğidir. Bu, bir millet ve devletin insanlığa karşı terörizm, bölücülük, sınır dışı etme ve soykırım politikaları konusundaki 1srarcı tutumunun bir göstergesidir (Hüseynov, 2019, s.270274).

Ancak karşılaştırma yapmak gerekirse, İslam dünyasının birçok köşesinde, Türkiye, Azerbaycan ve diğer ülkelerde Ermeni kilisesi bulunuyor. Günümüz Türkiye'de bir azınlık olan Ermeniler serbestçe, uyum ve beraberlik ortamında yaşamakta, kendi geleneklerini, dini vecibe ve ayinlerini serbestçe icra etmektedirler. Bu durum Amerikalı Ermenilerin Türklerle ilgili yaptıkları karalama kampanyalarıyla asla örtüşmemektedir. Günümüzde İslam dinin terörle ilişkilendirmeye çalışan Avrupa bu gerçekleri 
görmezden gelmektedir. Uluslararası hukukla ilgili çifte standart, din ve mezhepler konusunda farklı tutum sergilemeleri geçekleri algılama ve idrak etme ihtimalini, maalesef hiçe indirmektedir.

Öte yandan İslam'ın artan nüfusu ve İslam gerçeklerini idrak etmeye yönelik Avrupalıların eğilimleri Batı çevrelerini tedirgin etmektedir. Bu yüzden ellerindeki nüfuz araçlarını kullanarak bu eğilimleri engellemeye çalışıyorlar. Bunda başarısız oldukları zaman çağdığı ve demokratik olmayan "mücadele" yöntemlerine başvuruyorlar. Özellikle "İslam terörü destekler" ve "ona sadıktır" (Hüseynov, 2018, s.36-43) gibi düşüncelerle toplumu sindirmeye, korkutmaya ve durumu manipüle etmeye çalışıyorlar.

Ancak dünyaca tanınan Ermeni terör örgütlerinin faaliyetleri ve işledikleri terör eylemleri Hıristiyan toplumları tarafından bilinmektedir. Ne yazık ki bu eylemlere karşı uygulanabilecek hukukî yaptırımlar yetersizdir. Mesela, Temmuz 1983'te Paris'teki Orly Havaalanında sekiz kişiyi öldüren ve 60 kişiyi yaralayan terörist saldırıda müebbet hapis cezasına çarptırılan terörist Varojian Garabedyan'ın serbest bırakılması için Ermenistan'da devlet düzeyinde bir imza kampanyası başlatılmıştır. Nisan 2001'de bir Fransız mahkemesi tarafından serbest bırakılan teröriste Ermenistan tarafından resmi sığınma hakkı verilmiştir.

Batı Avrupa'daki ASALA Devrimci Hareketi adlı terör örgütünün elebaş1 Monte Melkonian, 28 Kasım 1985 'te altı yıl süreyle hapis cezasına çarptırılmış, fakat 1990'da bir Fransız cezaevinden salıverilmiş ve Dağlık Karabağ'daki terör faaliyetlerine devam etmek için Ermenistan'a dönmüştü. Melkonyan, Azerbaycan'in Hocavend bölgesinin işgali sırasında Ermeni terör örgütünün komutanıdı. 1993 yılında Erivan'da Dağlık Karabağ'da öldürülen teröristin cenazesine Ermenistan Cumhurbaşkanı da dahil olmak üzere yetkililer katıldı. Savunma Bakanlığı'nın sabotaj merkezlerinden birine Ermenistan'ın ulusal kahramanı ilan edilen bu uluslararası teröristin adı verilmiştir (Supremecourt, 2020).

$\mathrm{Bu}$ benzeri onlarca olay Avrupalıların uluslararası terörizmin ayrılmaz bir parçası olan Ermeni terörüne kayıtsız kaldığının, uluslararası terörizme karşı mücadelede samimi olmadıklarını göstermektedir. Görünen şu ki uluslararası terörizmle mücadeledeki gerçek hedef ilan edilmiş hedeften tamamen farklıdır. Aksi takdirde Amerika Birleşik Devletleri ve Avrupa ülkeleri, NATO üyesi Türkiye'yi PKK'ye karşı mücadelede yalnız bırakmayacak, dahası bu mücadeleden çekindirmek için yaptırım tehdidinde bu- 
lunmayacaktı. Başka bir deyişle, dünya ABD'nin terörizmle mücadelede ortak politika izlemediği, çifte standart sergilediği açık şekilde ortadadır. Yani Hristiyanlık ekseninde terör politikası yürüten Ermenistan devletine destek verilmekte, saldırıya uğramış devlete karşı baskıcı politikalar uygulanmaktadır. Bu mantığa dayanarak ASALA, Haydad, PKK, El Kaide, IŞiD ve diğer terör örgütlerine Batı ülkeler tarafından doğrudan destek verilirken dünya kamuoyunda İslam karşıtı bir hava oluşturulmaya çalışılmaktadır. Oysa bu devletler İslam'ın teröre karşı olduğunun, insana değerleri her şeyin üstünde tuttuğunun farkındadırlar.

Uluslararası hukukta ikili yaklaşım devletlerin çıkarlarından ileri gelmekte olup jeopolitik ve ve jeostratejik çıkarlarına dayanmaktadır. Başka bir ifadeyle uluslararası güçler, ekonomik ve siyasi çıkarları ve ulusal çıkarlarına öncelik vermektedirler. Bu bakımdan büyük güçlerin jeostratejik ve jeoekonomik üstünlügü bölgeleri sürekli kontrol altında tutmak ve kendine bağımlı hale getirmek günümüzde yaygin gözlemlenen eğilimlerdendir.

Batı'nın bugün Türkiye'ye karşı kullandığı ve Avrupa Birliği ile bütünleşmesini engelleyen önemli faktörlerden birinin sözde "Ermeni soykırımı"dır belirtilmelidir. Ermenilerin Azerbaycanlılara yönelik terör eylemlerine, 26 Şubat 1992'deki Hocalı soykırımına ABD tarafından tepki verilmezken yaklaşık 100 yıl önce Türkiye'de Ermenilerin bir bölgeden diğerine tehcirinin bir soykırım olarak değerlendirilmesi ve birçok ülkenin parlamentoları tarafından tanınması son derece manidardır. Amerika Birleşik Devletleri ve Batı'ın uluslararası politikalarındaki bu çelişki açık bir şekilde ortaya çıkmaktadır: bir yandan Ermenistan ve Dağlık Karabağ'daki teröristlere mali yardım sağlarken diğer taraftan küresel çapta teröre karşı mücadele operasyonları yürütülmektedir.

Bugün insanlığa sahte "Ermeni soykırımı" olarak sunulan "Ermeni kırımları"nın fikir babası 1913-1916 yıllarında ABD'nin Osmanlı'da görev yapmış büyükelçisi Henry Morgenthau olmuştur. Osmanlı İmparatorluğu'nun parçalanmasıyla isteyen ABD Başkanı Woodrow Wilson, Morgenthau'yu büyükelçi olarak atarken, "yakında Türkiye adlandırılabilecek hiçbir şeyin izi kalmayacağını" söylemiştir. Morgenthau, İstanbul'a gelir gelmez Ermeni liderler ve komite üyeleriyle temasa geçerek onları silaha sarılma konusunda ikna edebilmişti. Hatta birkaç Ermeni'yi kendi yardımcısı olarak atamıştır. Görevi sırasında Washington'a Ermenilerle ilgili yanlış bilgiler gönderirken, daha sonradan bu bilgilere dayanarak yazdığı kitabında 100.000 Erme- 
ni'nin öldürüldügünü iddia etmiştir. "Ermeni soykırımı"nın ikinci fikir babası, Anadolu'da misyonerlik yapmış ve 1914'te Alman-Ermeni Cemiyeti'ni kurmuş olan Johann Lepsius'tur. Bu cemiyetin amac1, Almanya'nun Anadolu'daki etkisini artırmaktı (Qazıyev, 2009, s.16).

Konuya bu açıdan ele aldığımızda Batı dünyasının ve Rusya'nın Ermenilere destek verdiğini, Türkiye'yi etki altında tutmak için Ermeni faktörünü kullandığını, potansiyelini yıpratmaya çalıştığını, ayrıca zengin petrol ve doğalgaz yataklarına sahip Azerbaycan'dan birtakım kazanımlar elde etmek için bu faktörü kullandığını görmekteyiz. Aksi takdirde, bugün hem Batı dünyası hem de Rusya uzun zamandır Ermeni terörizmine, şovenizmine ve saldırı politikalarına son vermiş olurdu. Batı'nın jeopolitik, Rusya'nın emperyalist ve saldırgan çıkarları doğrultusunda Ermeni faktörü maalesef, bundan sonra da kullanilacaktır.

\section{Sonuç}

Bugün, Ermeni Kilisesi tarafından desteklenen ve korunan Ermeni terörü, sadece Türkiye ve Azerbaycan açısından değil insanlık açısından ciddi bir suçtur. Uluslararası güçler uluslararası terörizme karşı mücadele verdiği bir zamanda çifte standartlardan el çekilmelidir. Günümüzde maalesef milletler arasından ziyade dinler arası bir çatışmaya doğru gidildiği gözlemlenmektedir. Teröre yardım ve yataklık eden Ermeni Kilisesi'nin organize bir şekilde diğer dinlere ve halklara karşı düşmanca tavrı asla kabul edilmez. Ermeni örgütlerinin 19. yüzyılın sonlarına doğru başlattıkları yoğun faaliyetler Türkiye ve Azerbaycan topraklarını hedef almıştır. Uluslararası güçlerin bu durumu görmezden gelmesi Ermeni terörünü daha fazla cesaretlendirmektedir. Yüzyılı aşkın bir sürede sadece sivil insanlar değil aynı zamanda tarihi abideler ve topyekûn olarak iskân birimleri Ermeni terörünün hedefi haline gelmiştir. Yaşanan olaylar sonucunda ölüm ve işkencelerin yanı sıra yüz binlerce Türk yurtlarından edinmiş, kırımlara ve soykırıma maruz kalmıştır.

Maalesef "Hristiyan dayanışması" sergileyen Batı dünyası Ermeni yalanlarını gerçek olarak kabul etmekte ve tanıtmaktadır. Yabancı güçler tarafından himaye edilen Ermenistan Cumhuriyeti Güney Kafkasya'da tehdit kaynağı olarak kalmaktadır. Ermeni terörü dünya kamuoyu tarafından gereken tepkiyi almadığı, hak ettiği muamele ve yaptırımlara maruz kal- 
madığı sürece terörizme karşı adil ve etkin bir mücadeleden bahsetmek anlamsizdir.

Günümüzde dünyasının içinde bulunduğu ağır şartları dikkate alarak uluslararası terörizme terör eylemlerinin faillerine ve azmettiricilere, ayrıca terörü destekleyen, ona yardım ve yataklık eden devletlere ve örgütlere karşı kararlı mücadele etmek son derece önemlidir. Sorunun çözümüne reel, gerçekçi ve sağduyulu yaklaşım sergilendiği takdirde Ermenistan'ın terörist devlet niteliği tüm dünya tarafından kabul edilecek ve gelecekteki terörist faaliyetleri engellenebilecektir. 


\title{
EXTENDED ABSTRACT
}

\section{Armenian Terror Under The Protection of the Armenian Church Summary}

\author{
Elnur Paşa \\ Osmaniye Korkut Ata Üniversitesi
}

The article reflects the issues of the Armenian Church as a religious subject of terrorism and its protection of Armenian terrorism. If we refer to historical facts and official documents, we can see that the church undoubtedly made the first contribution to the formation of the ideological basis of Armenian terrorism, their organization and access to financial resources. This is not accidental. The Armenian Church, along with its role in preserving Armenian traditions, has taken the first steps in the development of Armenian nationalism. Thus, both Western missionaries and the Gregorian Church have strongly supported the advancement of this policy and separatism. Even in the absence of the Armenian state, the Gregorian Church began to act not only as a religious, but also as a political protector of the Armenian community. To be more precise, the concentration of Armenians around the church shows that they did not have a state and a tradition of statehood. It was from here that the clergy themselves became more involved in political activity and political propaganda. They wanted the population to support various political and military forces, and even collected donations for this purpose. The Gregorian Church, which took refuge in the Arab caliphs and was protected by foreign invaders and thus betrayed its neighbors, began to spread Gregorianism through its missionaries to the local Albanian-Christian population in the neighboring territories, as well as in certain areas of Caucasian Albania. Then he began the Armenianization of the forcibly Gregorian Albanian-Azerbaijani tribes. Thus, the religious sphere of influence of the Gregorian Church expanded to the South Caucasus during the Caliphate.

In particular, the attitude of Russia and European countries to Armenian terrorism and chauvinism is explained as the subject of the research: Undoubtedly, if we pay attention to the historical processes, we can see that Russia has been the biggest supporter and protector of the Armenians in the 
South Caucasus for almost three hundred years in the implementation of separatist and vandalist intentions. Taking advantage of this, the Armenian chauvinists who took refuge in Russia managed to achieve their great goals - occupation, deportation and terrorism. Also, from time to time, using the support of the Russians, they even betrayed the Ottoman Empire and the Azerbaijani state, which once gave them great privileges. As can be seen from the analysis, this insidious policy of the Armenians not only served them, but also the interests of Russia, which protected them.

If one of the important goals of Peter I's march to the South Caucasus region was undoubtedly the use of the Armenian factor to strengthen Russia's future position in the region. Peter the Great instructed his agents in the South Caucasus to determine the force or role that Russia could rely on there. Considering that the characteristics of betrayal and treachery are unique to Armenians, it was decided to use them as vassals. This feature of the Armenians created the conditions for the creation of a Christian state that Tsarist Russia could trust and would be an important tool in the implementation of its policy in the Caucasus. In order to implement this strategic and purposeful plan, Azerbaijan pursued a policy of exterminating first the pro-Turkish Sunni population and then the pro-Iranian Shiite population.

Along with the issues mentioned in the study, the terrorist acts carried out under the direct financial support and patronage of the Armenian Gregorian Church, covering a period of more than a century, and their consequences are discussed. The purpose of committing terrorist acts is also the desire of Armenians to pursue policies of chauvinism, separatism and aggression against other nations. Unfortunately, opinions about Armenians and their terrorist organizations are often found and substantiated in the books and writings of Christian scholars. Political circles and the ruling class avoid openly acknowledging the truth. At the same time, they are trying to hide the direct support of a Christian state and the Christian Church for terrorism, financial support and organized terrorist acts. However, the terrorist acts carried out in the above-mentioned cities prove that the target of Armenian terrorism is not excluded, even non-Muslims, Christian nations.

It can be concluded that the intentions of the Armenians to create and expand their state at the expense of other people's lands are once again reflected. One of the important points mentioned in the article is the reasons 
for the non-objective attitude of Christian Europe to the Armenian terror, the lack of a legal assessment of the activities of the Armenian Church. Historical comparisons, parallels, researches conducted on the basis of the approach of different researchers allow to determine the true nature, realities, goals and objectives of Armenian terrorism.

\section{Kaynakça / References}

Abdullayev, B. ve Ceferov, H. (2002). Azerbaycanllara qarşı Ermeni terrorizminin qısa xronologiyası. Bakü: Elm Neşriyat.

Армянский геноцид: миф и реальность: справочник фактов и документов. Баку: Азернешр, 1992, 341 с.

Azerbaycan Respublikasının Prezidentinin İşler İdaresinin Siyasi Senedler Arxivi (ARPï̈SSA). Fond 276, siy. 8 (79), $72-74$.

Brief Information of the History of Garabagh. Heydar Aliyev Foundation Presents (2005). The Series of "The True Facts About Garabagh", 12.

Ermeniler Terrorizmin En İyrenc Formasından İstifade Edirler. (28 Şubat 2004).Bakü, Azerbaycan Qezeti

Haydad ve ASALA Ermeni Terror Teşkilatları (2001). Hüquqi dövlet ve qanun. 4-5, 77-79.

Esat, U. (1987). Tarihte Ermeniler ve Ermeni meselesi. İstanbul: Belge Yayınları.

Ermenistan Respublikası Terrörü Destekleyen Dövletdir. (2020). Ermenistan Respublikası Terrörü Destekleyen Dö̈letdir 29.06.2020 tarihinde http://www.supremecourt.gov.az/static/view/15 adresinden erişilmiştir.

Ehmedov, E. (2012). Ermenistanın Azerbaycana tecavüzü: Tehlili Xronika: 1987-2011. Bakü: Letterpress.

Gunter, M. (1986). Contemparary Armenian терроризм. Терроризм: An International Journal. 8(3), 24.

Hüseynov, R. (2018). Müasir münaqişelerin dövletlerin milli tehlükesizlik sistemlerine tesiri. Herbi Bilik Jurnal. 1,36-43.

Hüseynov, R. (2019). Terrorizmle Mübarizenin semeresizliyi: Terrorizmin genişlenmesinde siyasi faktorlarn rolu. Maqnityumşaq Erintilerin İnformasiya Texnologiyalarmda ve Herbi Senayede Tetbiqi Perspektivleri: Beynelxalq Elmi-Praktik Konfransı, 09-10 Ekim 2019, 270-274, Bakü.

Hüseynov, R. ve Memmedov, Ş. (2019). Ermenilerin Azerbaycanlılara qarşı soyqurım siyasetinin mühüm terefleri. H.Eliyev Adma AAHM-in Elmi Eserler Mecmuesi Jurnal. 2 (33), 16-21.

Hüseynov, S. (1999). Ermeni xeyaneti: Terror, soyqurm ve deportasiya siyaseti. Bakü: Avropa Neşriyyat Servis MMC. 
İmanov, R. (2006). Qondarma Dağlıq Qarabağ muxtar vilayetinin yaranması tarixinden. Bakü: AzTU - nun Metbeesi.

Kennet, K. (2002). Terörizm: Orta Doğuda terör örgütleri ve terörü destekleyen devletler. Ankara: Avrasiya Dosyası.

Qazıyev, Y. (2009). Ermeni meselesi: Yalanlar ve gerçeklikler. Bakü: Qafqaz Universiteti, Qafqaz Araşdırmaları Neşriyyatı.

Qurbanov, M. (2004). Ermeni terrorizmi. Bakü: Borçalı.

Qurbanov, M. (2005). Armenian terrorism. Bakü: Sabah.

Mahmudov, Y. (2009). Böyük Ermenistan uydurması: Terror, soyqurımları ve özge torpaqlarına yiyelenmek "ideologiyası". Dövlet Ve Din. 4, 83-90.

McCarthy, J. ve McCarthy, C. (1989). Turks and Armenians: A manual on the Armenian guestion. Washington: Committee on Education, Assembly of Turkish American Associations.

Memmedov, İ. ve Esedov, S. (1992). Ermenistan Azerbaycanlları ve onlarm acı taleyi: Qısa Tarixi oçerk. Bakü: Azerneşr.

Memmedov, İ. (2002), Tariximiz, torpağımız, taleyimiz. Bakü: Adiloğlu.

Memmedov, X. ve Memmedov, N. (2006). Türkiyede ve Azerbaycanda Ermeni Milletçilerinin Cinayetleri. Bakü: Elm.

Mustafayeva, A. (2002). Qadınlar ve beynelxalq terrorizmin qlobal tehlükesi problemleri. Dirçeliş. 54,139-149.

Novruzoğlu R. (2002). Azerbaycan Neft strategiyasının reallaşmasına Ermeni terroru mane faktoru kimi. Dirçeliş. 57, 112-113.

Rau, J. (2008). The Nagorno Karabakh conflict between Armenia and Azerbaijan. A Brief Historical Outline. Berlin: Dr. Köster.

Samuel, A. U. (2004). Ermenistan terrorçu "xristian" ölkesinin gizlinleri. Ermenilerin böyük firldaqları seriyası. Bakü: Oka Ofset.

Гумбатова, Т. (2006). Неправедные дела армянской церкви. "Вышка", 19 (19611) от 12 мая 2006 года.

Шавров, Н. (1990). Новая угроза русскому делу в Закавказье: предстояшая распродажа Мугани инородцам. Баку, 82 с.

\section{Kaynakça Bilgisi / Citation Information}

Paşa, E. (2020). Ermeni Kilisesinin Koruması Altındaki Ermeni Terörü. OPUS-Uluslararası Toplum Araştırmaları Dergisi, 16(31), 4588-4608. DOI: 10.26466/opus.787716 